\title{
Structural Repair to Conserve Langkawi's Main Tourist Attraction: Practical Approach
}

\author{
Maziah Mohammad ${ }^{1}$, and Ros Asmah Zahari2,** \\ ${ }^{1}$ Centre of Technical Excellence for Engineering and Technology, Public Works Department, Ministry of Work, Malaysia \\ ${ }^{2}$ Maintenance and Development Unit, Polisas, Ministry of Higher Education, Malaysia
}

\begin{abstract}
Direct exposure to marine environment causes accelerated corrosion process of all reinforced concrete structures, consequently, causes cracks, deterioration and overall reduction in the sstructural integrity. The aim of this paper is to study the deterioration and technique of repair work at Eagle Square as a landmark of Langkawi Island. Most of the structural problems which occurred at the splash zone were spalling and delamination on beam, slab and pile cap. Material testing was carried out at selected locations to obtain detailed information relating to the extent and causes of deterioration of the structure. The result showed that the carbonation depth was smaller than concrete cover and the amount of chloride ions was $0.23 \%$ by mass of cement and $50 \%$ of the splash zone was having $90 \%$ probability of corrosion. After obtaining the necessary data, the study directed towards deciding the remedial work. The Eagle Square structure members were successfully repaired in eight (8) months with proper works planning and repair technique appropriate to the damages.
\end{abstract}

\section{Introduction}

Dataran Lang, also known as Eagle Square, built in 1996, is a landmark located at the southeast corner of Langkawi Island. After 20 years the Eagle Square suffered the harmful damage at the structural members of the main sculpture platform. The marine environment conditions which are characterized by high sulphates, high conditions of chlorides, high temperature and relative humidity are the accelerating factors for the corrosion of steel reinforcement ${ }^{[1]}$. This severe corrosion of steel reinforcement causes wide cracks and spalling of concrete members at splash zone.

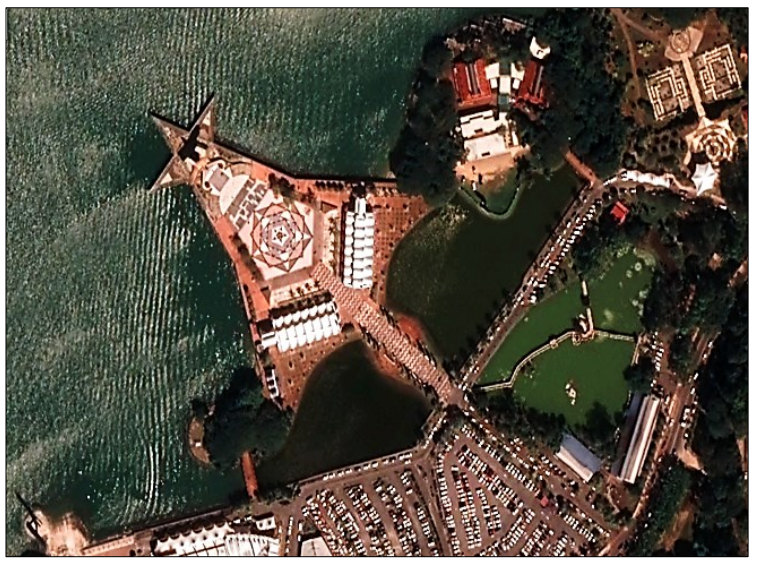

Figure 1. Aerial view of the Eagle Square Main Sculpture Platform.
The deterioration at the main sculpture platform had affected the panorama of Eagle Square. Various international events are held at Eagle Square and draw tourist from all over the world. It was imperative, therefore, that the execution of remedial works must include proper planning, high standard of site cleanliness, minimal disturbance to the public and high level of safety of everyone in the vicinity. The main objective of the remedial works was to extend the service life and enhance the overall structural integrity of Eagle Square.

\subsection{Confirmatory Inspection Works}

\subsubsection{Visual Inspection}

One of the most versatile method in the evaluation of concrete structure is visual inspection. This was the first step of evaluation and coupled with crack mappings for quantitative interpretation of the damage. The principal focus of this investigation generally involved recording the nature and extent of the obvious defects and identifying the affected members ${ }^{[2]}$. Photographic records were also used in classifying the conditions and structural problems.

\subsubsection{Material Testing}

Material testing was performed to ascertain the as-built structure, assess the extent of the deterioration and determine the probable cause of deterioration. Few destructive tests (DT) and non-destructive tests (NDT)

* Corresponding author: rosasmah@polisas.edu.my 
were carried out at four locations. The tests were carried out at only selected locations as indicative of the condition of the overall structure. The following in-situ and laboratory test were carried out:-

(a) Cover meter survey / Cover Measurement Test.

(b) Carbonation Test.

(c) Chloride and Cement Content Test.

(d) Half-cell Potential Measurement.

Table 1. Material Test Result.

\begin{tabular}{|c|c|}
\hline Average Cover & $45 \mathrm{~mm}$ \\
\hline $\begin{array}{c}\text { Average } \\
\text { Carbonation } \\
\text { depth }\end{array}$ & $22 \mathrm{~mm}$ \\
\hline $\begin{array}{c}\text { Average Chloride } \\
\text { Content }\end{array}$ & $0.23 \%$ by mass of cement \\
\hline $\begin{array}{c}\text { Hall Cell } \\
\text { Potential }\end{array}$ & $\begin{array}{c}\text { Approximately } 50 \% \text { of the splash zone } \\
\text { was having } 90 \% \text { probability of } \\
\text { corrosion. }\end{array}$ \\
\hline
\end{tabular}

Based on the test result, most of the concrete cover at Eagle Square was $45 \mathrm{~mm}$ compared to the standard $50 \mathrm{~mm}$ to $70 \mathrm{~mm}^{[3]}$. This inadequate cover had contributed to the premature delamination and spalling of concrete. The average carbonation penetration was $22 \mathrm{~mm}$.

Activation of corrosion has been found to occur at chloride levels of $0.4-0.5 \%$ by mass of cement, while high corrosion rates generally occur at higher chloride level ${ }^{[3]}$. However, the average chloride content at the main platform was $0.23 \%$ by mass of cement, so the corrosion of reinforcement expected to have occurred if no remedial works. The test results of half-cell potential showed $50 \%$ of the splash zone had $90 \%$ probability of corrosion. These results indicated that the protective film was destroyed.

Based on this information, general assessment of the structural elements was made and used to determine the repair methods.

\subsection{Determination of root cause of the problem}

From the visual inspection and materials tests, it was concluded that the concrete structures at the splash zone were affected more compared to the spray zone. The type of defects can be summarised as below:

(a) Spalling of concrete beam, slab and pile caps.

(b) Delamination of concrete beam, slab and pile caps.

(c) Crack on reinforcement beam, slab and pile caps.

The causes of defects at most of Eagle Square concrete structure was due to the carbonation process and chloride attack which led to corrosion of the steel reinforcements.

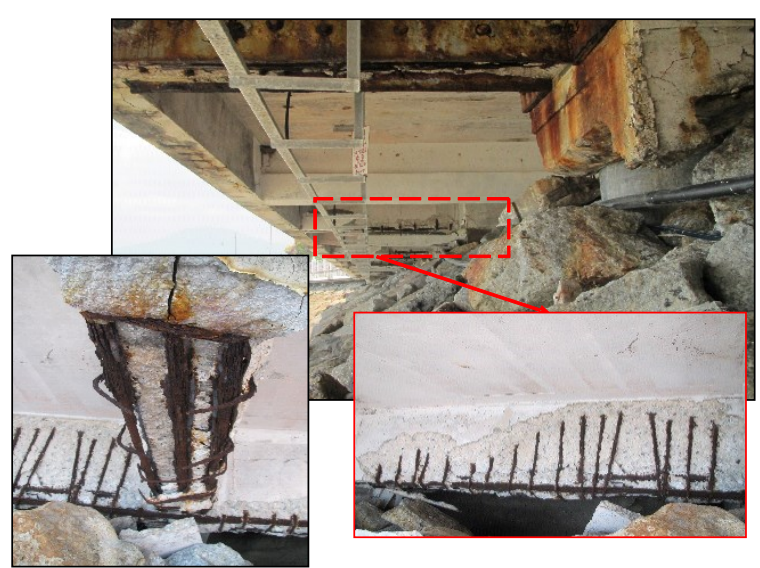

Figure 2. Spalled concrete beam

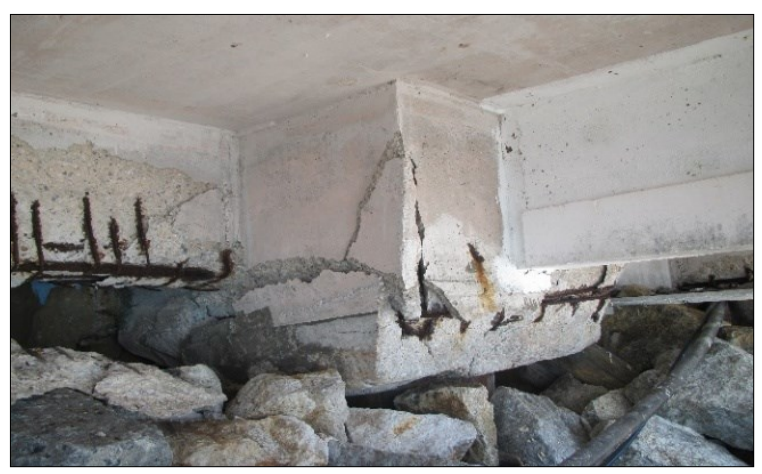

Figure 3. Delaminated and spalled concrete pile cap with exposed steel reinforcements.

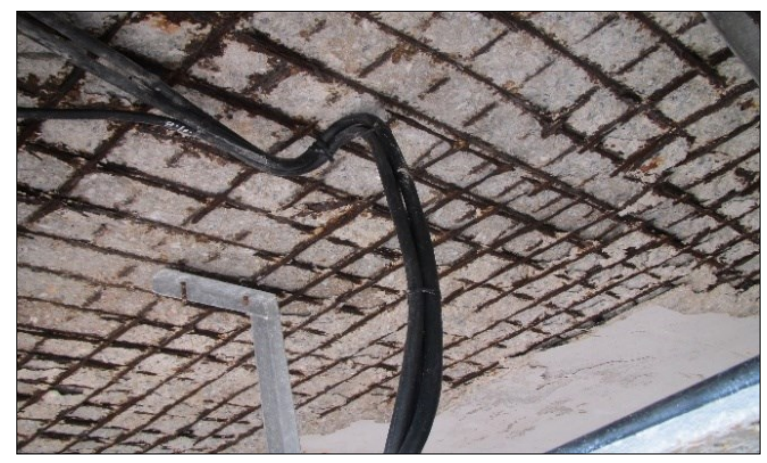

Figure 4. Extensively spalled concrete at soffit of slab

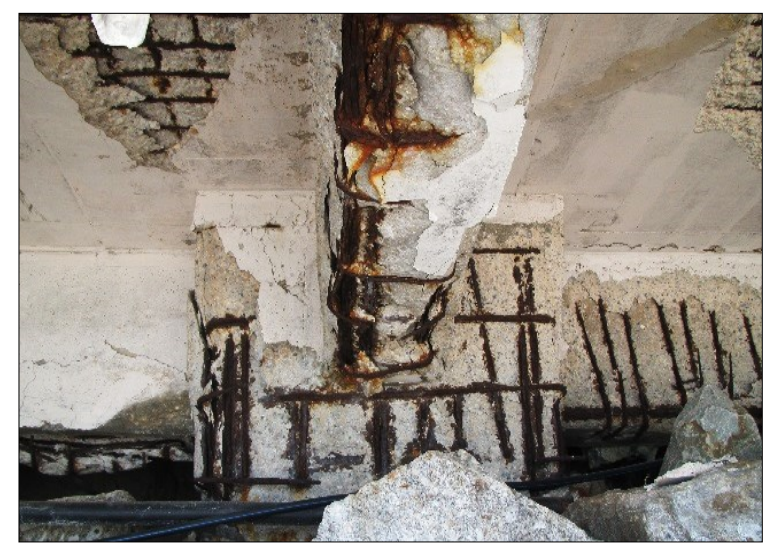

Figure 5. Corroded steel reinforcements at beam area. 


\section{Structural Treatment}

The remedial work was done by a nominated contractor under direct supervision by the state office of Public of Works Department (PWD, Malaysia). The activities, work breakdown structure and materials were approved before the commencement of the work. It was crucial to study the overall planning sequences taking into account the expected crowd following the events that were preplanned by the authorities. The remedial method was completed as follows:

Table 2. Remedial method for Eagle Square structural defects.

\begin{tabular}{|c|l|l|}
\hline Item & \multicolumn{1}{|c|}{ Defects } & \multicolumn{1}{c|}{ Remedial Method } \\
\hline 1 & $\begin{array}{l}\text { Delamination \& } \\
\text { spalling of RC } \\
\text { beam, slab and pile } \\
\text { cap }\end{array}$ & $\begin{array}{l}\text { Hand Patching \& Formwork } \\
\text { Pressure Grouting }\end{array}$ \\
\hline 2 & $\begin{array}{l}\text { Cracks in RC beam } \\
\text { and slab }\end{array}$ & Structural Crack Sealing \\
\hline 3 & $\begin{array}{l}\text { Steel reinforcement } \\
\text { corrosion due to } \\
\text { carbonation and } \\
\text { chloride attack }\end{array}$ & $\begin{array}{l}\text { Protective Coating } \\
\text { and } \\
\text { Replacement of corroded } \\
\text { steel rebar. }\end{array}$ \\
\hline 4 & $\begin{array}{l}\text { Reduction of } \\
\text { reinforcement cross } \\
\text { sectional area }\end{array}$ & \\
\hline
\end{tabular}

\subsection{Preparation of Repair Work}

Besides the visual defects, light hammer method was used to verify the defects. The location of the defects was marked and verified by joint inspections by the contractor and the PWD officer. Due to the wide area, the demarcation was done by grid lines and panels where possible. The planning was crucial, taking into account the environmental and logistic limitations.

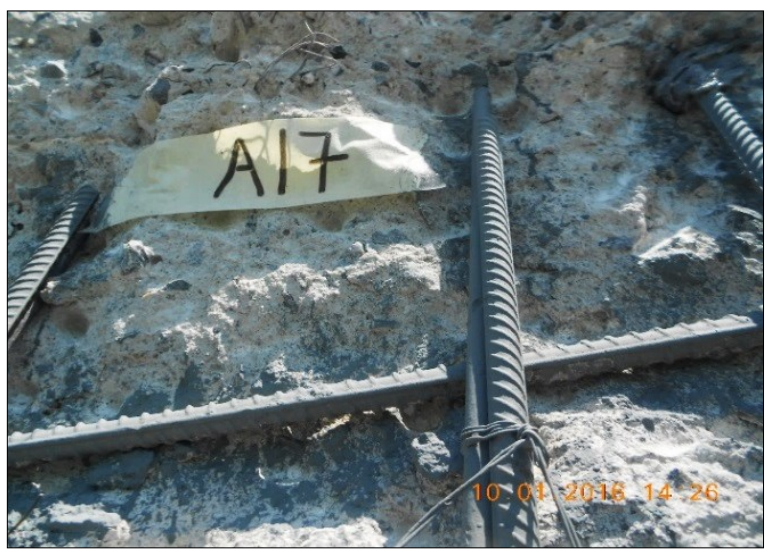

Figure 6. Number system at each panel of the structure members.

These limitations posed some challenges to the repair work at Eagle Square. There were limited accessibilities and working spaces underneath the main platform. Although the structures need not be supported, adequate structural scaffolding was provided for the workers to ensure safety and stability. Suspended platform was erected for accessibility and space to complete the work. It was very crucial that the scaffoldings were strong to withstand the hostile environment and the load at the time of repair work. The temporary support was also designed strong enough to withstand the wave action.

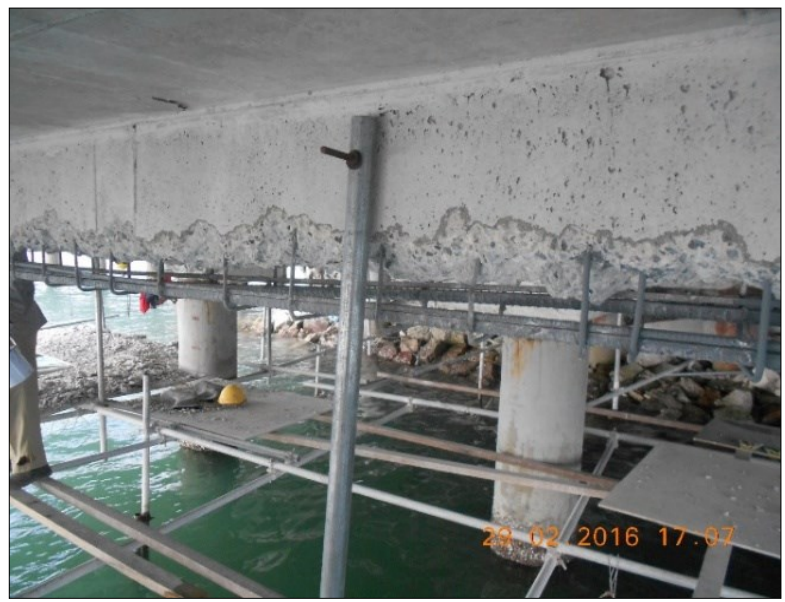

Figure 7. Sturdy support to ensure the secure and stable working platform for accessibility and work space.

The surface preparation of the structure prior to repair work is extremely important. All unsound and delaminated concrete was removed to expose sound concrete substrate up to minimum $20 \mathrm{~mm}$ behind the reinforcement ${ }^{[4]}$. The condition of the existing reinforcement was inspected by measuring the diameter of each reinforcing bar. If the cross-sectional area of the reinforcement is reduced by more than $10 \%$, then supplemental reinforcement was placed alongside the affected length.

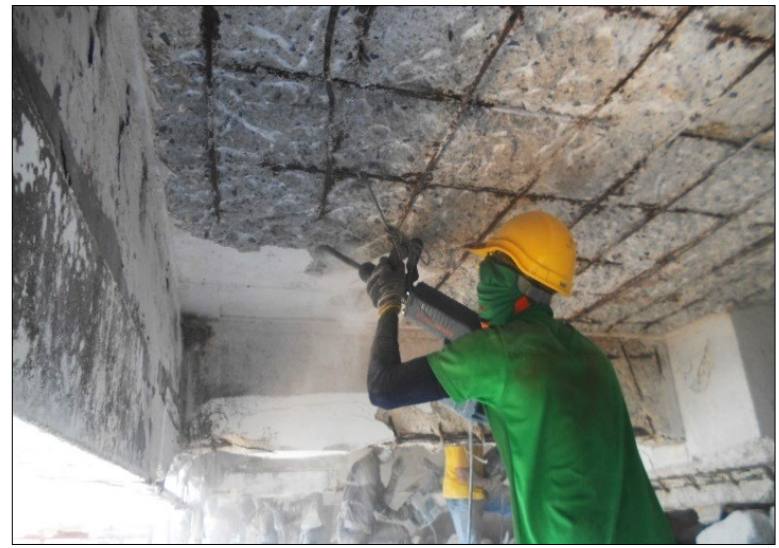

Figure 8. Removal of damaged concre hammer drills.

te using chipping

Rust removal and protective coats to the steel rebar are essential to ensure the good bonding and coating adhesion of repairs structure. All rust and deleterious matter were removed from the steel surface before application of zinc-rich coatings to all existing and new reinforcements.

It was applied to the steel reinforcements by hand using 
roller and wire brush. The application of zinc-rich was for the protection against corrosion ${ }^{[5]}$.

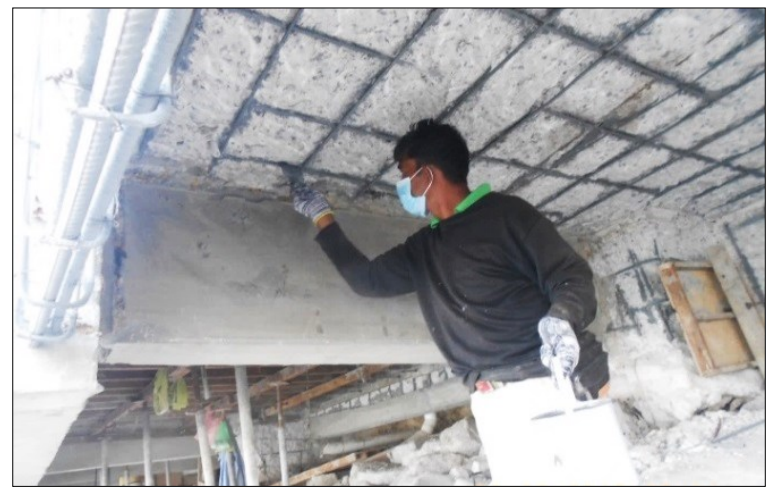

Figure 9. Application of anti-corrosion coating on existing and new steel reinforcement using brush

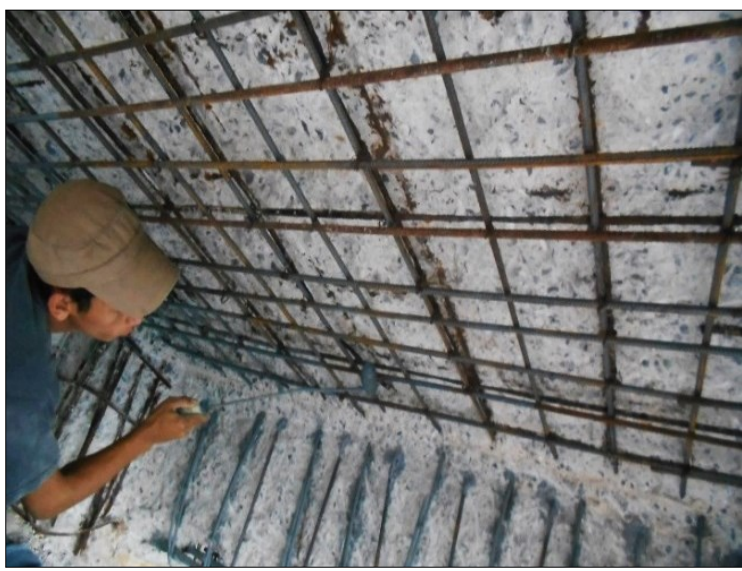

Figure 10. Application of anti-corrosion coating on existing and new reinforcements using roller.

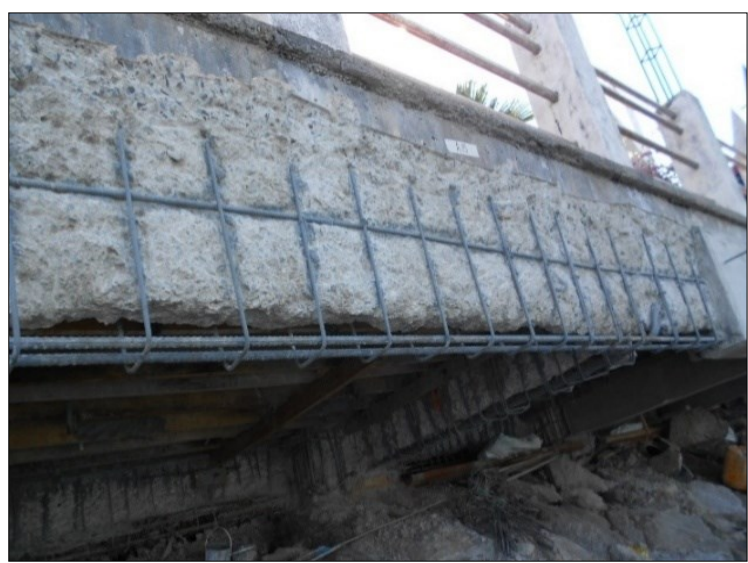

Figure 11. Completed anti-corrosion coating on existing and new reinforcements.

\subsection{Hand Patching}

Hand patching is a simple method where repair materials are hand applied in a towelling action.

Hand application has been used to repair vertical and overhead surfaces including walls, columns, beams, soffits, and building facades. Placement thickness can vary depending on the type of materials selected and the size, depth, and orientation of their pair cavity. Placement thickness can range from 3 to $70 \mathrm{~mm}$ (1/8 to $2-3 / 4 \mathrm{in}$.) on vertical surfaces, and 3 to $25 \mathrm{~mm}$ (1/8 to 1 in.) on overhead surfaces in a single layer ${ }^{[6]}$. The approved repair mortar used was polymer modified cementitious.

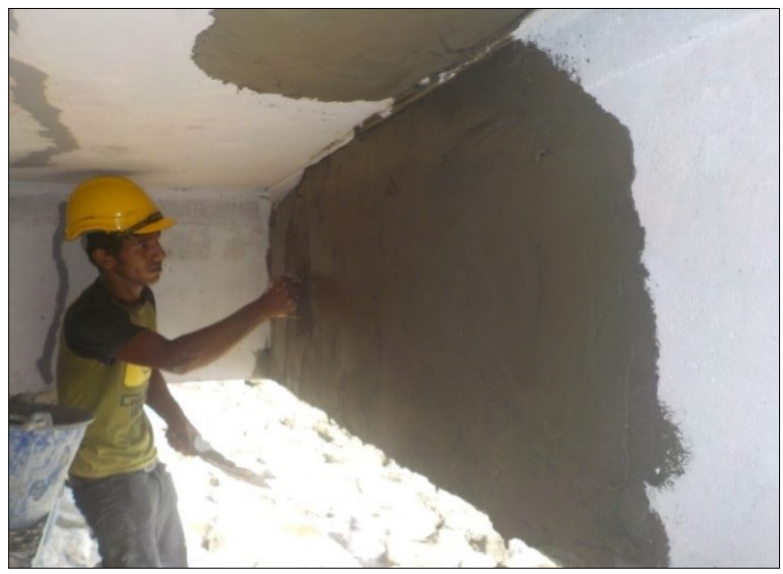

Figure 12. Hand patching at beam and soffit slab.

After the surface preparation was completed, a thin bonding coat was applied to all exposed surfaces. The subsequent polymer modified cementitious was applied while the bond coat was still wet or tacky. If the coat dries up before the application of the repair material, the concrete surface will be scrabbled to remove the old bond coat. The reinforcements were inspected prior to all application of the bonding coat and touched up, where necessary. ${ }^{[4]}$.

Repair patch was built up in layers and each layer was applied as soon as the preceding one was strong enough to support it. The application of repair mortar was built up to the original surface profile in layers not exceeding $16 \mathrm{~mm}$ and the final layer did not exceed $11 \mathrm{~mm}^{[4]}$. Sprayon curing was applied after the completion of patch works to keep damp in order to prevent drying out of cementbased repairs.

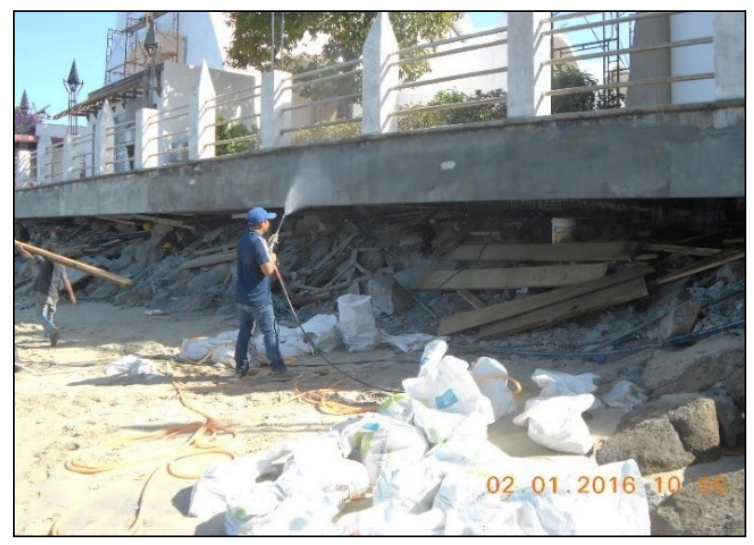

Figure 13. Spray-on curing at the finish surface.

\subsection{Formwork Pressure Grouting}

Hand application repair method was not appropriate at the splash zone due to the large scale of deterioration. 
Formwork was erected and filled with concrete grout using measured pressure. The surface preparation was similar to other methods of remedial works, where defective concrete was removed to the sound surfaces and the steel reinforcements cleaned. The existing diameters of the reinforcements were inspected and additional steel reinforcements were installed where necessary. The total area of reinforcement shall not be less than the cross sectional area of original reinforcement ${ }^{[7]}$.

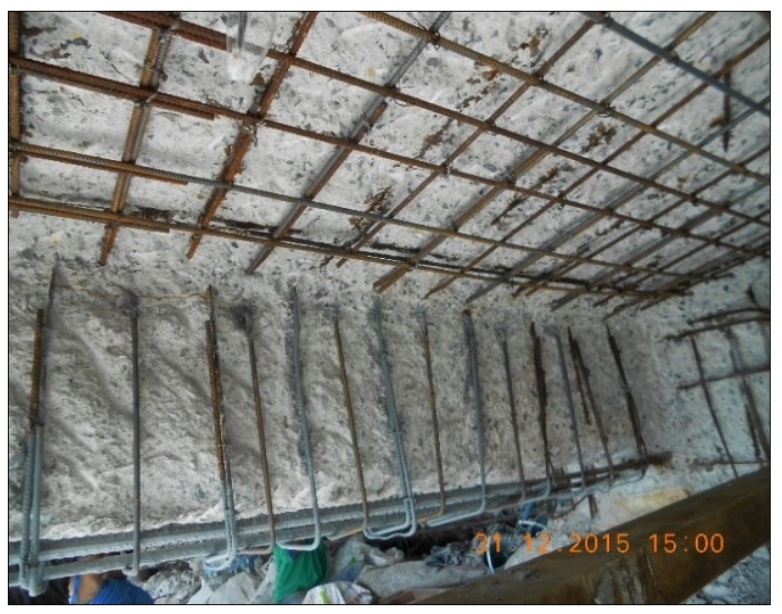

Figure 14. Supplemental reinforcement tied to the existing reinforcement.

Formwork pressure grouting is a method of injecting specially formulated cement based mixes under pressure. Air tight formwork was erected along the member and repair grout was pumped into the area through entry ports. All joints between section of formwork and existing concrete were sealed to prevent leakage. The formwork was built strong enough to maintain its shape during the process of compaction.

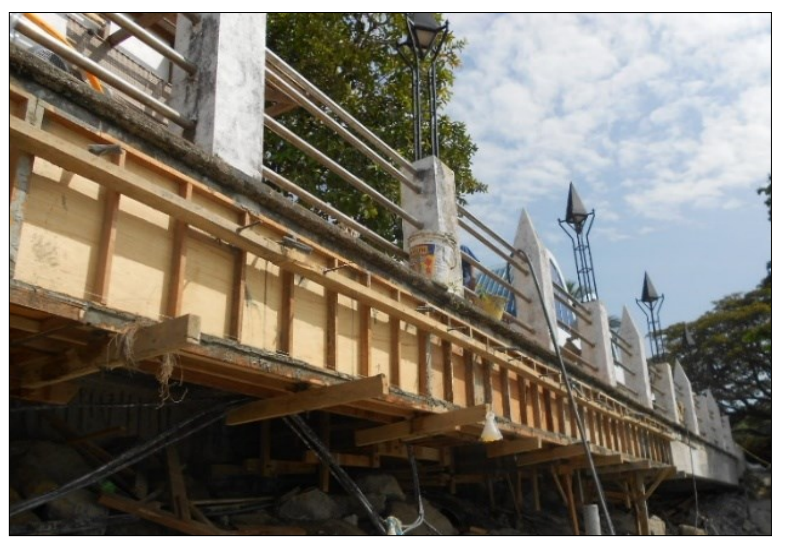

Figure 15. Air tight formwork installation along the length of the member.

Repair grout was injected at the bottom of the formworks through inlet port until the good steady flow of grout is expelled from the outlet port and immediately sealed off by closing the nipple. During the process, the injection rate and pressure must be controlled and checked to ensure that all voids were completely filled with the repair mortar. Hydraulic injection pump with pressure up to $0.275 \mathrm{~N} / \mathrm{mm}^{2}$ (40 psi) was used for injection of repair material ${ }^{[8]}$. Spray on curing was used after the removal of the formwork as indicated in the specifications ${ }^{[2]}$

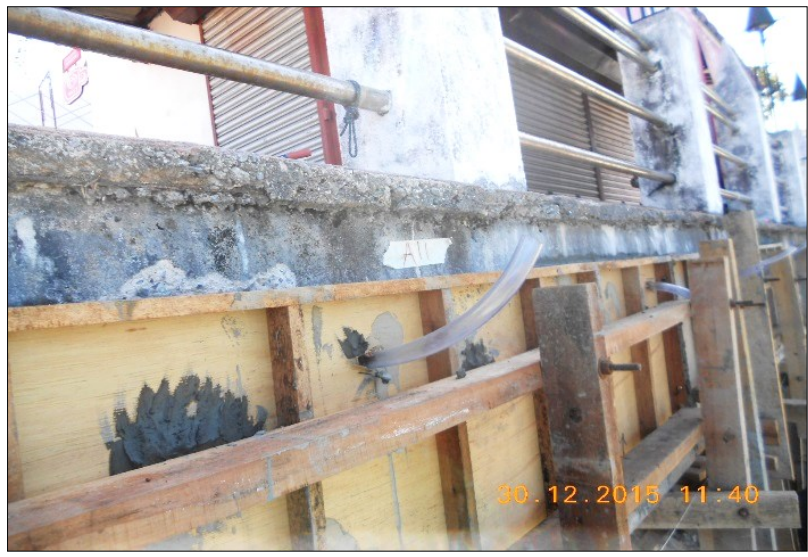

Figure 16. Outlet port for venting air at the top of formwork.

\subsection{Protective Coating}

A protective coating is a layer of material applied to the surface of another material with the intent of inhibiting or preventing corrosion. In this repair work, protective coating was applied to all exposed reinforced concrete surfaces on the beam, slab and pile caps. The protective coatings were applied using brush and roller depending on the area and location. Silane-based hydrophobic were used to protect chloride attack from sea water. Silane are silicon based products of low molecular weight which are recommend for use as hydrophobic impregnants for new concrete $^{[7]}$.

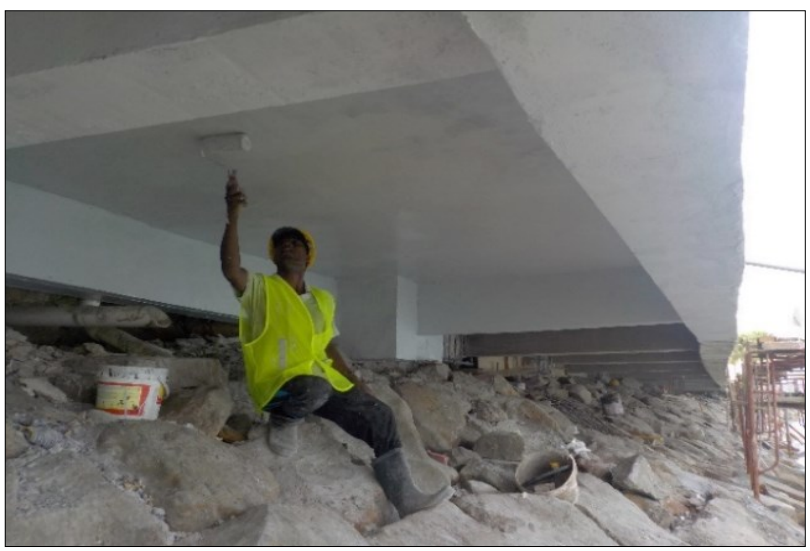

Figure 17. Protective coating applied to all exposed concrete surface using roller. 


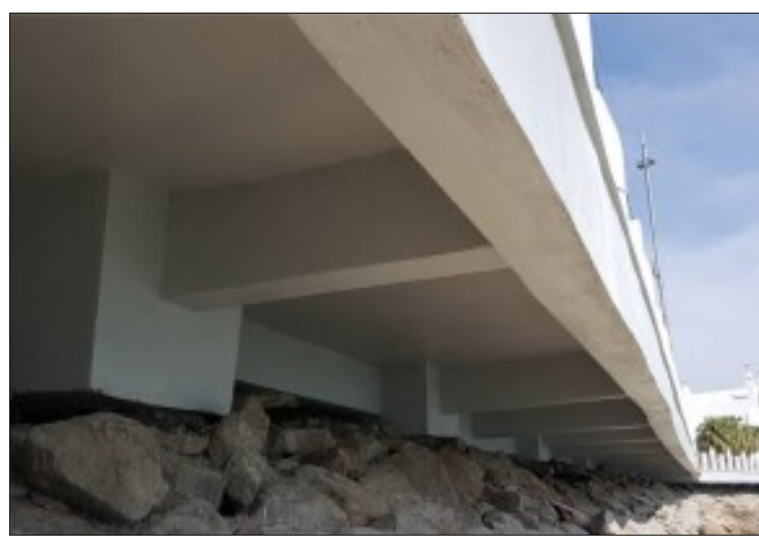

Figure 18. Newly repair and protected concrete surface.

\section{Conclusion}

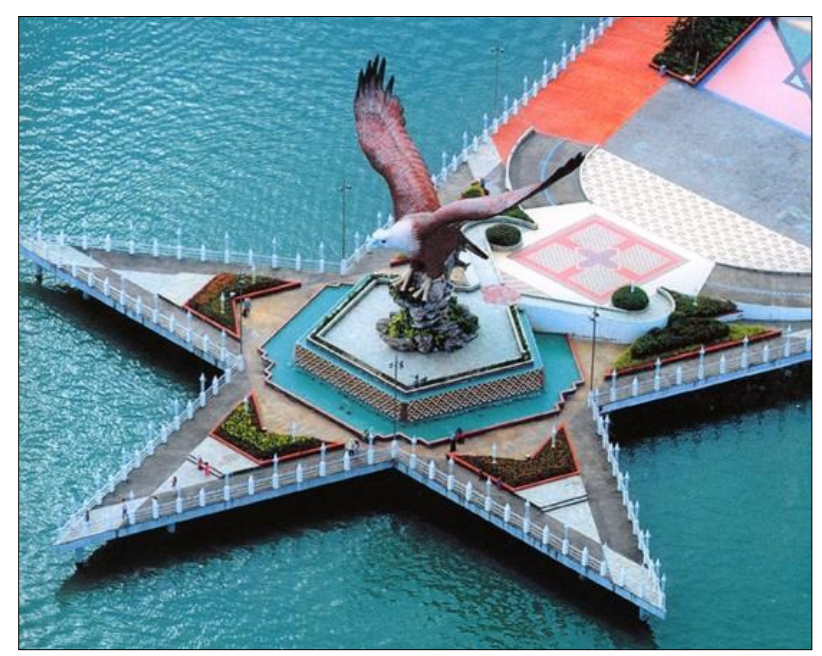

Figure 19. Eagle Square, Langkawi Island

The location of a marine structure at the highest risk of corrosion is in the splash zone. This exposure zone is subjected to constant wetting and drying from waves and has both chlorides and oxygen in abundance to initiate and prolong corrosion. Repair work at Eagle Square presents the unique challenge of carrying out the repairs safely and efficiently while keeping the facility open for normal use. This operational reality dominated technical, scheduling and logistic considerations which governed the repair work.

The structural repair work to restore the structures at Eagle Square, better known as Dataran Lang completed successfully. The restoration of Langkawi's main tourist attraction was crucial for a more intensive tourism culture and sports diversity. This is the first structural repair since its completion in 1996. However, deterioration is intrinsic to life, hence, the cycle of the repair process is expected although the interval depends largely on the previous restoration process, given the constant factors affecting the structure.

\section{References}

1. Nada M. Al- Galaw, Ali A. H. Al-Tameemi, Sarah H. Al-Jarrah, Effect of Age And Concrete Cover Thickness On Steel Reinforcement Corossion At Splash Zone In Reinforced Concrete Hydraulic Structure (2016)

2. Cawangan Pakar dan Kejuruteraan Awam, JKR Handbook for Building Conditions Inspection. (2008)

3. JR. Mackechnie, Predictions Of Reinforced Concrete Durability In The Marine Environment, (2001)

4. Cawangan Pakar dan Kejuruteraan Awam, JKR Specification for Concrete Patch Repair. (2012)

5. Hashem Al-Mattarneh, Azmi Ibrahim, Hamidah Mohd Saman, Repair and Enhancement of Concrete Structures (2004)

6. J. Christopher Ball, Vertical and Overhead Spall Repair by Hand Application, ACI RAP 6(2014)

7. R T L Allen, SC Edwards, Repair of Concrete Strucrure (1987)

8. Cawangan Pakar dan Kejuruteraan Awam, JKR Specification for Formwork Pressure Grouting. (2012) 